\title{
When Audience in a Theatre Used to Be a Natural Thing
}

\author{
Kateřina Šalounová
}

Petra Dotlačilová (ed.). 2020. Dance Actualities. Special Edition. (Dance and Audience). Prague: Dance Actualities, o. p. s., 2020. 129 s.

The Special Edition of Dance Actualities/ Tanečni aktuality is published once a year as a summarization of the dance events throughout the Czech Republic, but always complements this with discussions on an important dance-related topic. The first part of the 2020 issue summarizes the most significant performances from the ballet, contemporary dance, mime and non-verbal theatre and new circus. The journal (now in its third year of publication) has turned its attention towards the topic of how dance is perceived from a variety of different perspectives. The pandemic has of course made this topic much more relevant to the discussion of dance as an artform as well as a necessary conversation that practitioners must have with themselves going forward. The authors attempt to answer a series of relevant questions:

How do multi-company theatres and festivals build and take care of their audiences and how do creators see them? What does a spectator perceive when watching dance and what is the difference between young and adult audiences? How to engage viewers through the themes of dance productions or through the latest technologies? (2)
According the editor Petra Dotlačilová ${ }^{1}$, the Special is aimed at readers who are interested in the broader context of individual works, personalities and organizations but want a more theoretical approach to the subjects at hand. Compared with the previous issue of Tanečni aktuality, this more academic approach is obvious given the footnotes which were not present in the previous issues. These are mainly evident in texts written by Josef Bartoš ("What do we experience when we watch dance?") and Jana Bitterová ("Networked performance as a new situation for working with the audience"). Step by step, Dotlačilová and Josef Bartoš (Taneční aktuality's editor in chief) are transforming the Special into a professional journal serving as the theoretical platform for the online magazine Tanečni aktuality which is a space for further analysis of the topics they have discussed. Yet, it is not the editors' ambition to become an academic impact journal, turning to knowledgeable spectators and artists as well. The "Special" intends to dispel any appearance of elitism as dance as an artform is already pigeonholed throughout most of society.

1 Press release. 13th October 2020. Available online at https://www.tanecniaktuality.cz/zpravy/ prave-vychazi-specialni-vydani-tanecnich-aktualit2020-tanec-a-publikum. 
In fact, it can easily be argued that the perception of dance as an elitist practice rises from the Czech education system which prefers hard skills over soft skills. A spectator growing up in the Czech educational system then has no support in his own dance experience. The majority of society, therefore, has no desire to engage with dance productions because they feel uncomfortable with them. I therefore appreciate these efforts to raise public awareness of stage dance and broaden the horizons of society at large.

In four articles, the first section of the journal reflects the traditional season summary of ballet, contemporary dance, mime and new circus. Although Dotlačilová (p. 2) understands that genre classification of arts is becoming rather complicated and not very productive considering the internationality and multidisciplinary nature of art productions, the first section is nonetheless classified in this manner.

Roman Vašek ("The ballet half-Season relied on straightforward humour") shortly describes the strange, interrupted season full of recordings of performances or online classes, in which, in spite of everything, two new artists took the lead of the ballet company in Liberec (Marika Mikanová) and in Olomouc (Michal Štípa). Vašek primarily emphasizes Mikanová's productions, as he believes that she is "becoming a choreographer of strong theatrical imagery" (12). In his conclusion, the author confesses that the season was missing any extraordinary event.

Zuzana Smugalová ("Revealed trends in contemporary dance: Ideas versus reality") points out that "the art is mainly a cultural service to the society" (20), and that it in general has now reached the breaking point. She considers the potential of con- temporary dance and the appeal of using dance as a tool for education and professional growth as well as a function of the creative industry. Smugalová also comes to the conclusion, that

the most significant trend of contemporary dance today, however, is leaving the closed space of theatre halls and moving to urban and natural exteriors or reviving interesting architectural objects. In the context of the threat of coronavirus spread, this postmodern phenomenon has now become more established than ever before. (20)

Roman Horák summarizes the season of mime and non-verbal theatre ("Good news from the world of mime and nonverbal theatre") and focuses primarily on the founding of the Bravo Theatre by Radim Vizváry and the Losers Cirque Company. He anticipates further interconnection of the art of mime and the popular contemporary circus. We will see how Vizváry would be able to combine these activities with his post as the artistic director of Laterna magika in Prague, which was announced in January 2021.

The new circus's season was reviewed by Hana Strejčková ("A season of unforeseen possibilities and solidarity in new circus"), who appreciated the adaptability and flexibility of the genre. "Despite restrictive measures the contemporary circus art form is still very much alive, resiliently viable and demonstrably spontaneous" (36). Zuzana Smugalová calls this theatre season "ground-breaking" (16) and the majority of authors featured in the issue agree with her.

In 2020, Lucie Hayashi carried out field research concerning dance festivals throughout the country and collected 
data about "Audience development by the Czech dance festivals". She confirms what was mentioned above - the need to be open, accessible, and available to everyone in order to have a chance to become part of the educational system. Hayashi declares the need to pay attention and target a younger audience to popularize this field to the public. She especially emphasizes the need for marketing strategies and tools when organising dance performances and festivals. Her article is provocative and she lets herself be carried away using directive vocabulary which serves to emphasise the seriousness of the situation.

According to Monika Štúrová ("How theatres take care of their audiences"), the coronavirus crisis could open new ways and possibilities to get closer to and communicate with audiences. She summarizes the means theatres use to take care of their audience, mentioning preperformance talks, ballet workshops for the whole family, ballet-themed art competitions, autograph sessions, theatreoperated ballet studios, feedback in public inquiries and on social networks and streams of the productions or viral videos. The following article ("Contemporary dance for young audiences”) by $\mathrm{Lu}$ cie Štádlerová contributes to the known perspectives of educational support for young spectators and also the possibility of education via dance. Štádlerová mentions the most important authors (e. g. Barbora Látalová, Mirka Eliášová), productions (e. g. Dance and Physic, Animal Carnival, interPlay) and organizations (Ostružina, Dance for Schools, SE.S.TA) from this field. She defines a quality performance for children in which it is important to take into consideration both children and their parents (who do not want to feel embarrassed). [...] Parents accompanying their children expect to see art and experience something that would resonate with them and their children's knowledge and skills. In short, nobody expects fabricated and over-acted stories. People crave new experiences, new adventures, new ways of thinking about movement, the body and its capacities and limitations. (72)

Unfortunately, the current restrictions do not allow creators or children to meet and create, play or experiment. These activities have been officially forbidden for almost a year (which was not obvious in the time of the closing date of the Special Edition), so the future of the above-mentioned artists and organizations is somewhat in doubt. Daniela Machová ("Socially engaged practice in Czech contemporary dance") focuses on the contemporary situation of socially engaged Czech dance. Based on the views of contemporary dance theorists, critics and artists, she interprets the socially engaged practice in general as art is naturally integral to politics. Nevertheless, she notices that some creators and their productions are more engaged than others (e. g. Farm in the Cave, Miřenka Čechová, Ufftenživot). It appears that foreign dancers give "their views on social and political issues much more often" (78) but Machová also deals with the topic in Czech socially engaged dance. She defines four main topics: 1. Czech history and historical events, 2. Global issues, 3. Abusive tendencies in today's society, 4. Exploration of the body and physicality and its image in today's society. Towards the end of her paper Machová refers to 
the overarching theme of the special issue - to the audience, which is often stimulated by casual moves, gestures, naked bodies, resourceful scenography, installations, projections, site specific spaces or dance interventions in unusual places conversely, Machová appreciates the courage and experience of a dancer.

Josef Bartoš immersed himself in the theory the most. He asks the basic question: "What do we experience when we watch dance?" He reminds the reader of some theorists (Otakar Zich, Jan Reimoser, John Martin), who were dealing with the imitative perception of dance. Their concepts were followed by the interdisciplinary project Watching Dance: Kinesthetic Empathy, whose outcome, the mind map, is published in this article. Czech readers have an opportunity to familiarize themselves with the terms and concepts accompanying the process of watching dance in a graphic form. Furthermore, Bartoš briefly presents the conceptual integration and its application to the theatre experience citing its most significant proponent, Bruce McConachie. He also explains the term flow, mentioning the Chicago-based Hungarian psychologist Mihály Csikszentmihályi and McConachie. It would nevertheless be beneficial for the reader if Bartoš could integrate the term flow more organically into his discussion.

Petra Dotlačilová ("Dancers: Watching and being watched") begins her articles by pointing out the polarization of two camps, critics and artists. In her article, consisting of views and standpoints of more than ten Czech dancers and choreographers, she attempts to dismantle this dichotomy as she puts the artists in the position of the spectators. For example, Dotlačilová was interested in the ways of how to communicate with the audience. All the artists directly rejected manipulation of the audience and pandering to them. The article also asked the question whether the performance is authentic when it is composed with the consciousness of spectators. Does this art piece become meaningless or insincere? It is hard to say, because for many respondents the ideal spectator has these characteristics: open, courageous, capable of feedback, enthusiastic, emphatic, perceptive and curious. It turns out that the artist's willingness to attend productions "depends on the creative and the life phase in which the artist finds himself" (110). The artists as spectators primary appreciate a charismatic personality albeit technically imperfect. "Some are extremely demanding and critical, while others are grateful and tolerant" (114). Eventually, Dotlačilová points out that the nature of a spectator is highly individual, no matter whether one is an artist or an amateur.

In her article, Jana Bitterová deals with the possibilities of combining the internet with live performances ("Network performance as a new situation for working with the audience"), a concept that was already on the increase before the coronavirus pandemic and, their purpose, the live sharing of art and the connecting of groups of people, has only grown and become more relevant and valuable in these troubled times. The author analyses the specifics of the genre providing "the collective experience of an audience located physically together, but expands it through the Internet, connecting viewers and artists in different places, in distant cities, countries and continents" (116). She also refers to the definition posited by Ian Biscoe in his doctoral thesis $X$ Reality Networked Performance from 2020 where he defines the net- 
worked performance as "an artistic performance that occurs simultaneously across physically distributed spaces, and which by means of a communication network allows the participants to collaborate in a single event" (118). As a follow up to this definition, Bitterová describes the typology of this phenomenon considering the relationship with the audience.

There are very few misprints compared to the previous issue. However, I am still sceptical about the fragmented graphics. The editorship approached the photographer Michal Hančovský and the choreographer Václav Kuneš, who became a model for the cover of the Special as well as its godfather. ${ }^{2}$ On the cover of the issue, Kuneš is standing in the darkness of an empty auditorium and gazes to his right. It

2 GROSSMANOVÁ, Michaela. Publikum je tématem nejen letošního Speciálu Tanečních aktualit. (Rozhovor s Petrou Dotlačilovou) [online] [cit. 202101-17]. Available online at <http:/ / www.czechcentres. cz/_sys_/FileStorage/download/49/48022/ rozhovor-specialni-vydani-2020.pdf>. is a pity seeing the professional photo on a bad-made cover of a magazine, but I understand the problems with funding these kinds of activities.

To conclude, the authors of the special edition of Tanečni aktuality were able to formulate their opinions on the current events of today, which they put in a relevant theoretical context. The main point of the collection is the idea that engaging with dance is a means of developing our empathy, openness, sensitivity, creativity, cognition, socialization, or exploration of boundaries. The idea of live sharing of experience became one of the more prominent aspects of the issue's main theme "Dance and Audience" before the pandemic. This message has only grown stronger now at the beginning of the year 2021. We are seeing clearly the need to participate in the public space during a performance and beyond, a notion that the Special precisely highlights. 